Supporting Information

\title{
Total Chemical Synthesis of ISGylated-Ubiquitin Hybrid Chain Assisted by Acetamidomethyl Derivatives with Dual Functions
}

Emad Eid, ${ }^{\#}$ Gábor N. Boross, ${ }^{\#}$ Hao Sun, Muna Msallam, Sumeet K. Singh, Ashraf Brik*

Schulich Faculty of Chemistry, Technion-Israel Institute of Technology Haifa, 3200008 (Israel)

E-mail: abrik@technion.ac.il 


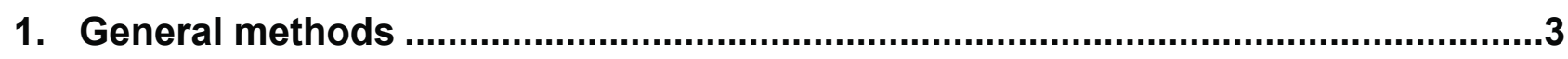

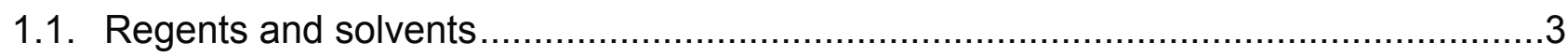

1.2. List of the protected amino acids used in peptides synthesis ..................................

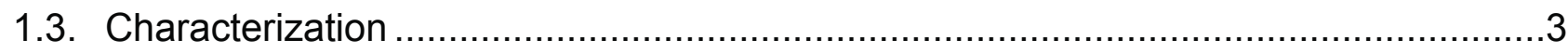

1.4. Reverse phased high-pressure liquid chromatography (RP-HPLC) …....................

2. Synthesis of the Acm-NMe $\mathrm{N}_{2}$ protected L-cysteine (3) .............................................

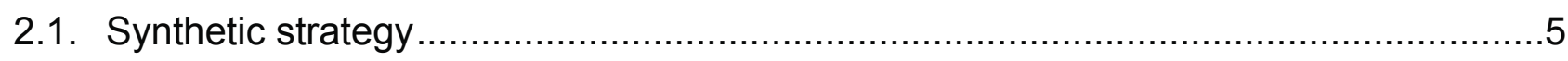

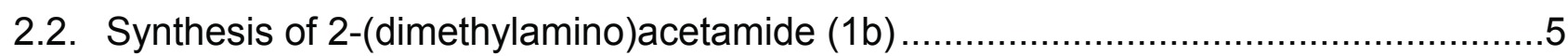

2.3. Synthesis of 2-(dimethylamino)-N-(hydroxymethyl)-acetamide (1) ….......................

2.4. Synthesis of S-[2-(dimethylamino)-acetamidomethyl]-L-cysteine trifluoroacetic acid

(2) 6

2.5. Synthesis of S-[2-(dimethylamino)-acetamidomethyl]-N-[(9H-fluoren-9-

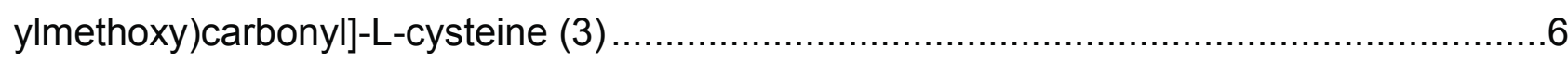

3. Synthesis of ISG15-Ub without Acm-NMe 2 group ..................................................

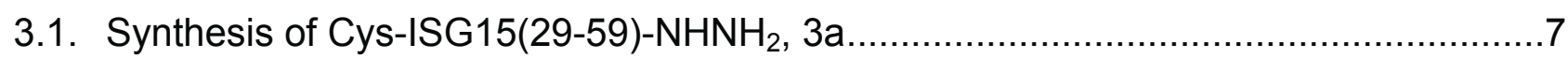

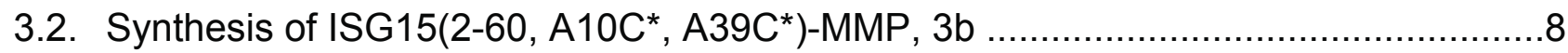

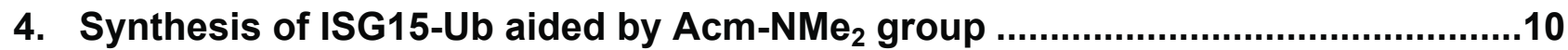

4.1. Synthesis of ISG15 (2-60) thioester segment (3) ............................................. 10

4.2. Synthesis of ISG15 (61-157) cysteine segment (4) ……................................12

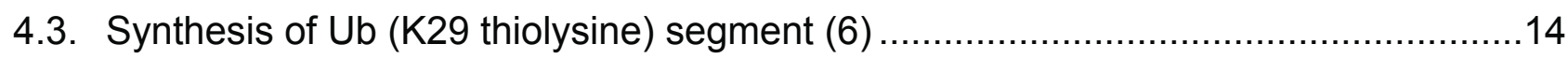

4.4. Assembly of the full length ISG15 by NCL and subsequent thioester conversion .....17

4.5. NCL ligation between full length ISG15 and ubiquitin fragment.............................18

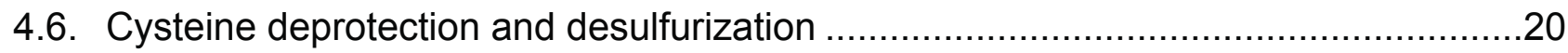

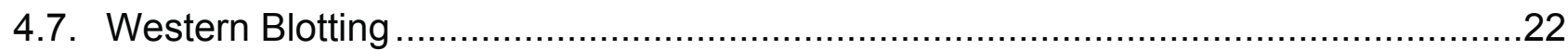

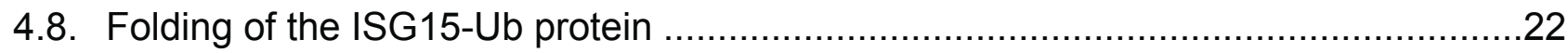

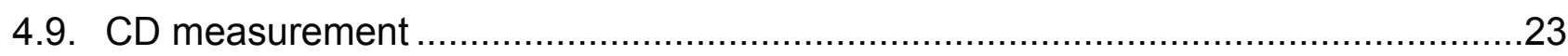

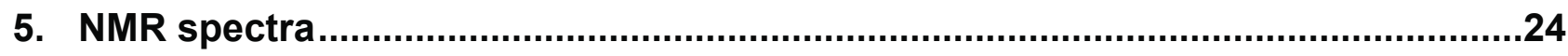

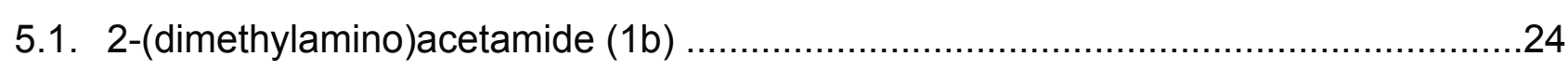

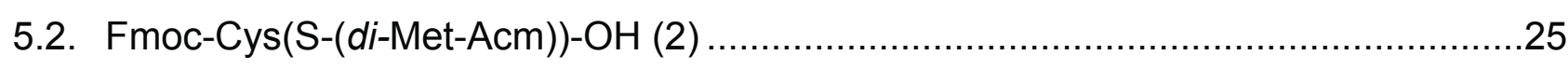




\section{General methods}

\subsection{Regents and solvents}

SPPS was carried out by using an automated peptide synthesizer (CS336X, CSBIO). Analytical grade $\mathrm{N}, \mathrm{N}$-Dimethylformamide (DMF), dichloromethane, and Trifluoroacetic acid (TFA) were purchased from Biolab. Diethyl ether and HPLC-grade acetonitrile (ACN) was purchased from Avantor. Chemicals and reagents were purchased from Aldrich, Alfa Aesar and Fluka. Resins were purchased from Creosalus and all protected amino acids were purchased from GL Biochem. The activating reagents [(2-(1Hbenzotriazol-1-yl)-1,1,3,3tetramethyluronium hexafluorophosphate (HBTU), hydroxybenzotriazole (HOBt), [6chlorobenzotriazol-1-yl)oxy(dimethylamino)methylidene]-

dimethyl-azanium hexafluorophosphate (HCTU), (1-[Bis(dimethylamino)methylene]-1H-1,2,3-triazolo[4,5b]pyridinium 3-oxide hexafluorophosphate (HATU) were purchased from Luxembourg Bio Technologies. Unless otherwise mentioned, all reactions were carried out at room temperature. Rink amide resin (100-200 mesh, $0.26 \mathrm{mmol} / \mathrm{g}$ ) was purchased from CreoSalus. MS-monoclonl Ub ab7254 antibody, Rb-monoclonal ISG ab133346 antibody, Rb-polycolnal ISG15 ab14374 antibody.

\subsection{List of the protected amino acids used in peptides synthesis}

Fmoc-Gly-OH, Fmoc-Ala-OH, Fmoc-Val-OH, Fmoc-Leu-OH, Fmoc-lle-OH, Fmoc-Phe-OH, Fmoc-Pro-OH, Fmoc-His(Trt)-OH, Fmoc-Asn(Trt)-OH, Fmoc-Gln(Trt)-OH, Fmoc-Arg(Pbf)$\mathrm{OH}$, Fmoc-Lys(Boc)-OH, Fmoc-Tyr(tBu)-OH, Fmoc-Ser(tBu)-OH, Fmoc-Thr(tBu)-OH, Fmoc-Asp(OtBu)-OH, Fmoc-Glu(OtBu)-OH, Fmoc-Trp(Boc)-OH,

\subsection{Characterization}

The ${ }^{1} \mathrm{H}$ and ${ }^{13} \mathrm{C}$ NMR spectroscopic data were recorded with $400 \mathrm{MHz}\left({ }^{1} \mathrm{H}\right.$ NMR: $400 \mathrm{MHz}$, ${ }^{13} \mathrm{C}$ NMR: $100 \mathrm{MHz}$ ) and $500 \mathrm{MHz}\left({ }^{1} \mathrm{H}\right.$ NMR: $500 \mathrm{MHz},{ }^{13} \mathrm{C}$ NMR: $125 \mathrm{MHz}$ ) Bruker Avence spectrometers. The ${ }^{1} \mathrm{H}$ and ${ }^{13} \mathrm{C}$ chemical shifts are given in ppm ( $\delta$ scale). Electrospray ionization mass spectrometry (ESI-MS) was performed on a LCQ Fleet mass spectrometer (Thermo Scientific) with an ESI source. 


\subsection{Reverse phased high-pressure liquid chromatography (RP-HPLC)}

Analytical HPLC was performed on a Thermo instrument (Dionex Ultimate 3000) using

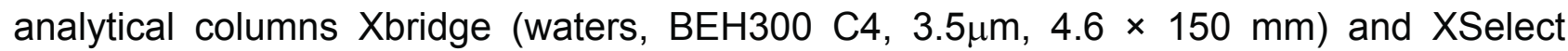
(waters, CSH C18, $3.5 \mu \mathrm{m}, 4.6 \times 150 \mathrm{~mm}$ ) at flow rate of $1.2 \mathrm{~mL} / \mathrm{min}$. Preparative HPLC was performed on a Waters instrument using Jupiter $5 \mu \mathrm{m}, \mathrm{C} 18 / \mathrm{C} 4300,250 \times 22.4 \mathrm{~mm}$ and XSelect (waters, C18, $10 \mu \mathrm{m}, 19 \times 250 \mathrm{~mm}$ ) at flow rate of $15 \mathrm{~mL} / \mathrm{min}$. Semi preparative HPLC was performed on a Thermo Scientific instrument (Spectra System SCM1000) using Jupiter C4 $10 \mu \mathrm{m}, 300 \AA, 250 \times 10 \mathrm{~mm}$ column, at flow rate of $4 \mathrm{~mL} / \mathrm{min}$. All synthetic products were purified by HPLC and characterized by mass spectrometry using LCQ Fleet Ion Trap (Thermo Scientific). All calculated masses have been reported as an average isotope composition.

Buffer A: 0.1\% TFA in water; buffer B: 0.1\% TFA in acetonitrile. 


\section{Synthesis of the Acm-NMe 2 protected L-cysteine (3)}

2.1. Synthetic strategy

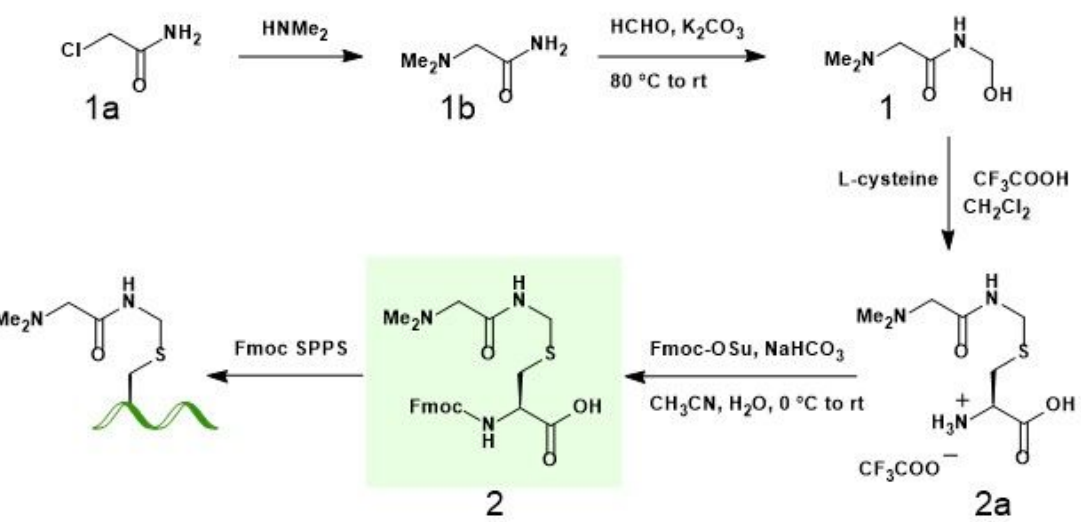

\subsection{Synthesis of 2-(dimethylamino)acetamide (1b)}

2-chloroacetamide, $1 \mathrm{a}(40 \mathrm{mmol}, 3.74 \mathrm{~g})$ was added to a stirred solution of dimethylamine 40 wt. \% in $\mathrm{H}_{2} \mathrm{O}$ (2.5 equiv, $12.6 \mathrm{~mL}$ ) at room temperature. After the reaction mixture was stirred overnight, the aqueous solution was extracted with chloroform (3X). The combined organic layers were washed with water, dried with $\mathrm{Na}_{2} \mathrm{SO}_{4}$, filtered, and concentrated under reduced pressure to get crude product as white solid, which was further recrystallized by using chloroform and hexane to afford the pure product $1 \mathbf{b}(3.7 \mathrm{~g}, 91 \%$ yield).

${ }^{1} \mathrm{H}$ NMR: $\left(400 \mathrm{MHz}, \mathrm{CDCl}_{3}\right) \delta 7.31$ (br s, 1H), 7.04 (br s, 1H), 2.95 (s, 2H), $2.32(\mathrm{~s}, 6 \mathrm{H})$

${ }^{13} \mathrm{C}$ NMR: $\left(400 \mathrm{MHz}, \mathrm{CDCl}_{3}\right) \delta 174.11,63.07,46.03$

MS (ESI): calculated for $\mathrm{C}_{4} \mathrm{H}_{11} \mathrm{~N}_{2} \mathrm{O}[\mathrm{M}+\mathrm{H}]^{+}:$103.09, found: 102.25

\subsection{Synthesis of 2-(dimethylamino)-N-(hydroxymethyl)-acetamide (1)}

To a solution of formaldehyde $(35 \%, 6 \mathrm{~mL})$, compound $1 \mathrm{~b}(30 \mathrm{mmol}, 3.06 \mathrm{~g})$ and $\mathrm{K}_{2} \mathrm{CO}_{3}$ ( 0.05 equiv, $1.5 \mathrm{mmol}, 211 \mathrm{mg}$ ) were added. The reaction mixture was stirred at $70^{\circ} \mathrm{C}$ for 5 min and then at room temperature for overnight. Then the mixture was concentrated and dried under vacuum to obtain the crude product as a colorless oil, which was directly used for the next step without further purification. 


\subsection{Synthesis of S-[2-(dimethylamino)-acetamidomethyl]-L-cysteine trifluoroacetic acid (2)}

To the stirred solution of the crude compound 1 from last step in DCM $(20 \mathrm{~mL})$, cysteine (30 $\mathrm{mmol}, 3.63 \mathrm{~g})$ and TFA $(20 \mathrm{~mL})$ was successively added. After stirring at room temperature for $30 \mathrm{~min}$, the solvent was evaporated to get the cured product $\mathbf{2 a}$, which was directly used for the next step without purification.

\subsection{Synthesis of S-[2-(dimethylamino)-acetamidomethyl]-N-[(9H-fluoren-9- ylmethoxy)carbonyl]-L-cysteine (3)}

The crude compound 2a from last step was dissolved in $\mathrm{CH}_{3} \mathrm{CN} / \mathrm{H}_{2} \mathrm{O}(1: 1,50 \mathrm{~mL})$. The solution was stirred at $0{ }^{\circ} \mathrm{C}$ and the $\mathrm{pH}$ was adjusted to 7 with solid $\mathrm{NaHCO}_{3}$. Another portion of $\mathrm{NaHCO}_{3}(2.2$ equiv, $66 \mathrm{mmol}, 5.5 \mathrm{~g}$ ) and $\mathrm{Fmoc}-\mathrm{OSu}(1.1$ equiv, $33 \mathrm{mmol}, 11.1 \mathrm{~g}$ ) was added, and the reaction mixture was stirred for overnight at room temperature. Then the reaction mixture was adjusted to $\mathrm{pH} 3-5$ with $1 \mathrm{~N} \mathrm{HCl}$ and extracted using ethyl acetate (3X). The combined organic layers were washed with brine, dried with $\mathrm{Na}_{2} \mathrm{SO}_{4}$, concentrated and purified using flash column chromatography (silica gel, $\mathrm{MeOH} / \mathrm{CH}_{2} \mathrm{Cl}_{2}$ 6/4) afforded compound 2 (13.7 g, $19.5 \mathrm{mmol}, 91 \%$ yield for three steps) as a white solid.

$\boldsymbol{R}_{\boldsymbol{f}}=0.30\left(\mathrm{MeOH} / \mathrm{CH}_{2} \mathrm{Cl}_{2}=6 / 4\right)$

${ }^{1} \mathrm{H}$ NMR: $\left(400 \mathrm{MHz}, \mathrm{CD}_{3} \mathrm{OD}-\mathrm{d}_{4}\right) \delta 7.73(\mathrm{~d}, J=7.5,2 \mathrm{H}), 7.61(\mathrm{t}, J=6.4,2 \mathrm{H}), 7.33(\mathrm{t}, J=7.4$, $2 \mathrm{H}), 7.25(\mathrm{t}, J=7.4,2 \mathrm{H}), 4.42-4.15(\mathrm{~m}, 6 \mathrm{H}), 3.83(\mathrm{~s}, 2 \mathrm{H}), 3.28-3.26(\mathrm{~m}, 1 \mathrm{H}), 3.16-3.11(\mathrm{~m}$, $1 \mathrm{H}), 2.81(\mathrm{~s}, 6 \mathrm{H})$

${ }^{13} \mathrm{C}$ NMR: $\left(400 \mathrm{MHz}, \mathrm{CD}_{3} \mathrm{OD}-d_{4}\right) \delta 175.04,164.85,156.96,143.97,143.82,141.16,127.42$, $126.82,124.93,119.56,66.64,58.32,55.51,43.21,40.98,34.10,23.88$

MS (ESI): calculated for $\mathrm{C}_{23} \mathrm{H}_{29} \mathrm{~N}_{3} \mathrm{O}_{5} \mathrm{~S}[\mathrm{M}+\mathrm{H}]^{+}: 458.17$, found: 458.25 


\section{Synthesis of ISG15-Ub without Acm-NMe 2 group}

\subsection{Synthesis of Cys-ISG15(29-59)-NHNH}

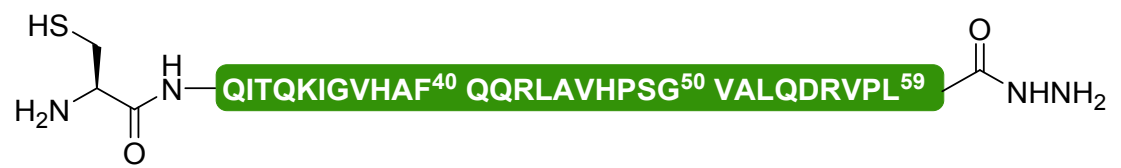

2-chlorotrityl chloride resin was let to swell in $10 \mathrm{ml}$ DMF: $\mathrm{CH}_{2} \mathrm{Cl}_{2}$ mixture (1:1) for 0.5 hours. The resin was washed 3 times with DMF and treated for 0.5 hours with $10 \mathrm{ml} 10 \%$ solution of hydrazine in DMF. The washing and the hydrazine treatment were repeated one time. The resin was capped by treatment of $5 \mathrm{v} / \mathrm{v} \% \mathrm{MeOH}$ in DMF for 0.5 hours two times. FmocLeu-OH (353.0 mg, 0.2 mmol, 1.0 equiv) was coupled on the resin for 20 hours using HATU (1.0 equiv) and DIPEA (2.0 equiv).

The peptide synthesis was performed on $0.2 \mathrm{mmol}$ scale on peptide synthesizer using standard Fmoc-AA-OH building blocks (4.0 equiv), HCTU (4.0 equiv) coupling reagent and DIPEA (8.0 equiv) for $0.5 \mathrm{~h}$ in DMF.

Samples were analyzed using analytical HPLC C18 column, with a gradient of 0-60\%B over 30 min. Finally, the peptide was cyclized and cleaved from the resin with the cleavage cocktail as mentioned above and purified using preparative HPLC C18 column with a gradient of $0-60 \% \mathrm{~B}$ over $30 \mathrm{~min}$.

A)

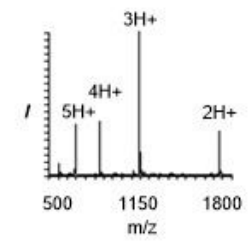

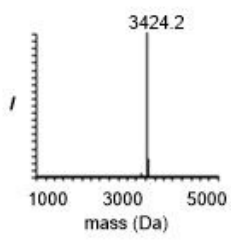

B)

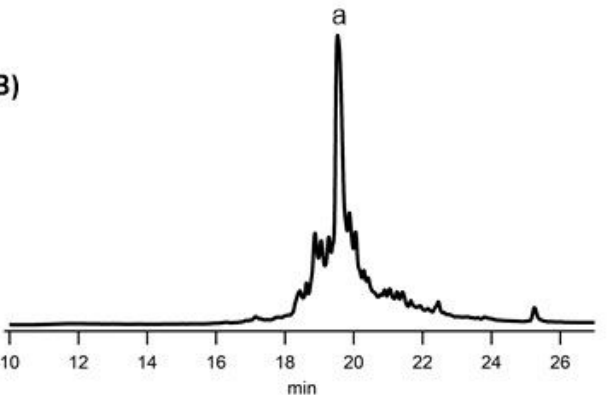

Figure S1: Synthesis of ISG15(29-59)-Nbz: A) Analytical HPLC of crude ISG15(29-59)-Nbz peak a corresponds to ISG15(29-59)-Nbz with the observed mass $3424.2 \pm 0.4$ Da; calcd 3423.9 Da. 


\subsection{Synthesis of ISG15(2-60, A10C*, A39C*)-MMP, 3b}

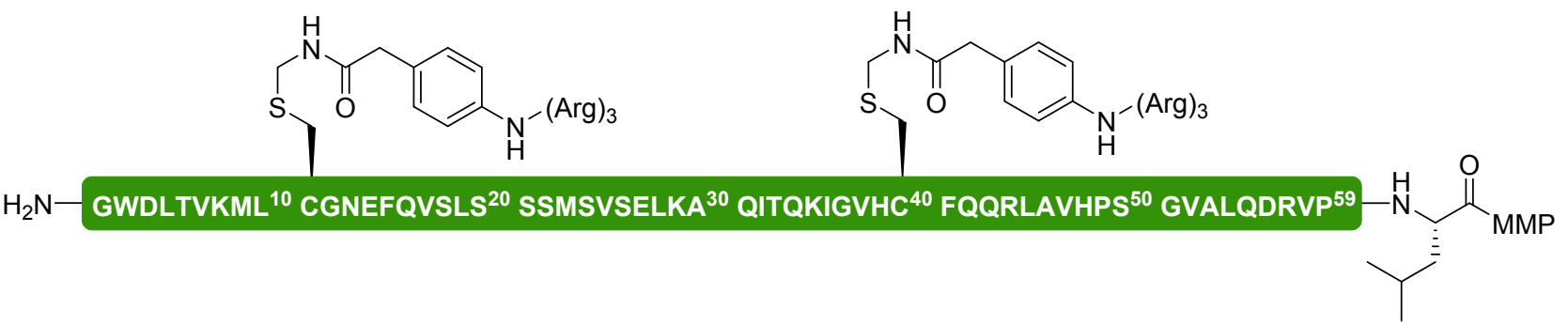

Fmoc-MeDbz was coupled with 4 equiv of HBTU, 4 equiv of HOBt and 8 equiv of DIPEA on Rink amide resin for $2 \mathrm{~h}$. This was followed by Fmoc deprotection and manual coupling of Leu60 with 4 equiv of AA, 4 equiv of HCTU and 8 equiv of DIEA for 45 min (2 cycles). The subsequent Fmoc-removal and the coupling of remaining amino acids were achieved using automated peptide synthesizer in presence of 4 equiv of AA, 8 equiv of DIPEA and 4 equiv of HCTU of the initial loading of the resin. In order to avoid unwanted oxidation, the methionine residues were replaced by norleucine using Fmoc-Nle-OH building block. Pseudoproline dipeptides were used in the cases of LT, SS, VS, IT. Fmoc-AASer/Thr( $\Psi$ Me,Me)-OH (2.5 equiv) were coupled using HATU (2.5 equiv) coupling reagent and DIPEA (5.0 equiv) for $2 \mathrm{~h}$ in DMF. In addition, the phacm linker was coupled manually at positions 10, and 39 using 2.5 equiv of Fmoc-Cys(Phacm)-OH, 2.5 equiv of HATU, and 5 equiv of DIEA for $2 \mathrm{~h}$. The last amino acid was coupled in the Boc protected form, followed by Alloc removal on the Phacm linkers and Arg coupling as follows:

Alloc-removal on Phacm linker: For $0.1 \mathrm{mmol}$ scale, Alloc deprotection on Phacm was carried out by treating with mixture of $\mathrm{Pd}\left(\mathrm{PPh}_{3}\right)_{4}(24 \mathrm{mg}, 0.020 \mathrm{mmol})$ and phenylsilane $(240$ $\mathrm{mL}, \mathrm{mmol}$ ) in $3 \mathrm{~mL}$ of dry DCM for $1 \mathrm{~h}$.

Arg coupling on Phacm: All the three Arg were coupled using automated peptide synthesizer as described above. The last Arg was coupled in the Boc protected from.

MeDbz cyclization: The resin was washed with DCM and a solution of p-nitrophenyl chloroformate (100 mg, 5 equiv) in $4 \mathrm{~mL}$ of dry DCM was added, shaken for $30 \mathrm{~min}$ at $25^{\circ} \mathrm{C}$ and washed with DCM $(3 \times 5 \mathrm{~mL})$. This step was repeated two more times. Following this, the resin was washed with DCM $(3 \times 5 \mathrm{~mL})$ and DMF $(3 \times 5 \mathrm{~mL})$, and a solution of $0.5 \mathrm{M}$ DIEA in DMF (5 mL) was added and shaken for $10 \mathrm{~min}$. this step was repeated for another two times to ensure complete cyclization. Finally, the resin was washed with DMF $(3 \times 5$ 
$\mathrm{mL})$.

Cleavage of the peptide from resin: Cleavage of the peptide from resin: A mixture of trifluoroacetic acid (TFA): triisopropylsilane (TIS): water $\left(\mathrm{H}_{2} \mathrm{O}\right)(95: 2.5: 2.5)$ was added to the dried peptide-resin and the reaction mixture was shaken for $2 \mathrm{hr}$ at RT. The resin was removed by filtration and was washed with additional TFA $(2 \times 2 \mathrm{~mL})$. To precipitate the peptide, the combined filtrate was added drop-wise to 10-fold volume of cold ether followed by centrifugation, decanting of ether and by dissolution of residue in acetonitrile-water for freeze drying in the lyophilizer.

Switching of Nbz to MMP thioester: The crude ISG15(2-60, A10C*, A39C*)-MeNbz (50 mg, $9.5 \times 10^{-3} \mathrm{mmol}$ ) was dissolved in $6 \mathrm{M} \mathrm{Gn} \cdot \mathrm{HCl}$ buffer $(1.5 \mathrm{~mL}, 6 \mathrm{mM})$. This mixture was treated with MMP $(120 \mu \mathrm{L}, 1.2 \mathrm{mM}))$ for $1 \mathrm{~h}$ at $37^{\circ} \mathrm{C}(\mathrm{pH} 7)$. The product was purified by preparative HPLC, using a gradient of 0-60\%B over 40 min to afford ISG15(2-60, A10C* ${ }^{*}$ A39C*)-MMP in overall $3 \%$ yield (from synthesis to the final product).

A)

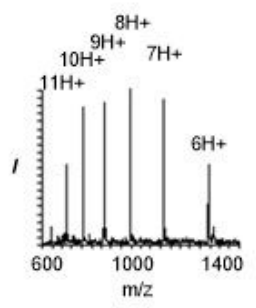

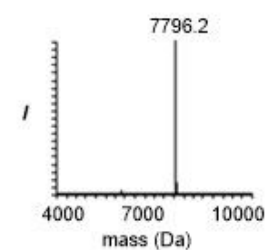

B)

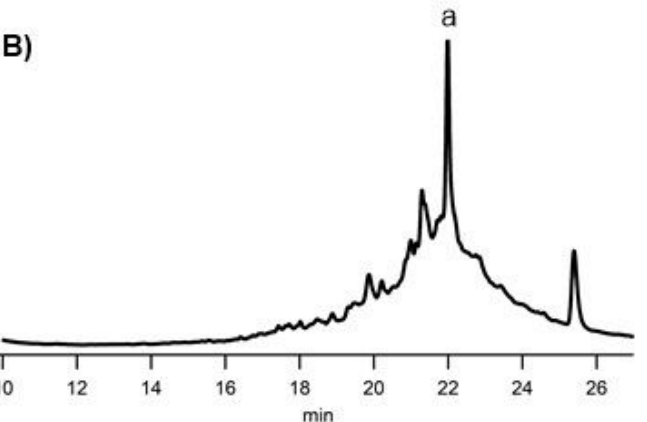

Figure S2: Synthesis of ISG15(2-60, A10C*, A39C*)-MMP: A) Analytical HPLC of crude ISG15(2-60, A10C*, A39C*)-MMP peak a corresponds to ISG15(2-60, A10C* A39C*)-MMP with observed mass 7796.2 $\pm 0.3 \mathrm{Da}$; calcd 7795.4 Da. ("stands for $\mathrm{Phacm}-\mathrm{Arg}_{3}$ solubilizing tag). 


\section{Synthesis of ISG15-Ub aided by Acm-NMe 2 group}

\subsection{Synthesis of ISG15 (2-60) thioester segment (3)}
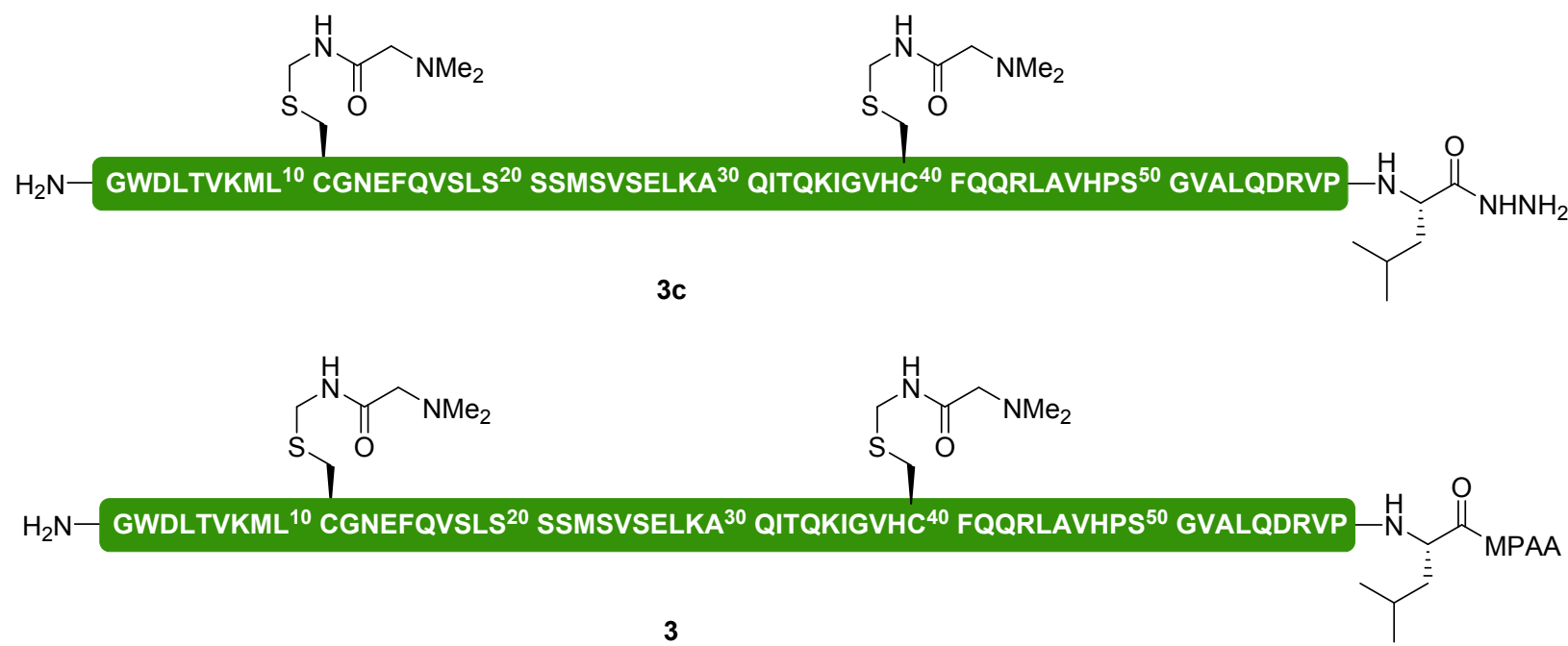

2-chlorotrityl chloride resin was let to swell in $10 \mathrm{ml} \mathrm{DMF:} \mathrm{CH}_{2} \mathrm{Cl}_{2}$ mixture (1:1) for 0.5 hours. The resin was washed 3 times with DMF and treated for 0.5 hours with $10 \mathrm{ml} 10 \%$ solution of hydrazine in DMF. The washing and the hydrazine treatment were repeated one time. The resin was capped by treatment of $5 \mathrm{v} / \mathrm{v} \% \mathrm{MeOH}$ in DMF for 0.5 hours two times. FmocLeu-OH (353.0 mg, $0.2 \mathrm{mmol}, 1.0$ equiv) was coupled on the resin for 20 hours using HATU (1.0 equiv) and DIPEA (2.0 equiv). After the coupling of the Fmoc-Leu-OH the resin was capped using $\mathrm{Ac}_{2} \mathrm{O}$ (10 equiv) and DIPEA (10 equiv) for 10 minutes.

Peptide synthesis was performed on $0.2 \mathrm{mmol}$ scale in manual fashion using standard Fmoc-AA-OH (4.0 equiv), HATU (4.0 equiv) coupling reagent and DIPEA (8.0 equiv) for 0.5 $\mathrm{h}$ in NMP, double couplings were performed in each time and after coupling the resin was capped with $\mathrm{Ac}_{2} \mathrm{O}$ (10 equiv) and DIPEA (10 equiv) in DMF for 10 minutes unless otherwise specified. In order to avoid unwanted oxidation, the methionine residues were replaced by norleucine using Fmoc-Nle-OH building block.

Pseudoproline dipeptides were used in the cases of LT, SS, VS, IT. Fmoc-AASer/Thr( $\Psi M e, M e)-O H ~(2.5$ equiv) were coupled using HATU (2.5 equiv) coupling reagent and DIPEA (5.0 equiv) for $2 \mathrm{~h}$ in DMF. The capping was performed as described above.

The cysteine residues were coupled using Fmoc-Cys(Acm-NMe 2 )-OH (4.0 equiv), $\mathrm{HOBt}$ (4.0 equiv) and DIC (4.0 equiv) after 10 minutes of preactivation in DMF for 2 hours. The capping was performed as described above. 
The peptide was cleaved from resin with the following cleavage cocktail: $95 \mathrm{v} / \mathrm{v} \%$ TFA; 2.5 $\mathrm{v} / \mathrm{v} \%$ DODT; $2.5 \mathrm{v} / \mathrm{v} \% \mathrm{H}_{2} \mathrm{O}$ for 2 hours at rt. $10 \mathrm{~mL}$ cleavage cocktail was used for $1 \mathrm{~g}$ of peptidic resin. After 2 hours the resin was filtered off and peptide was precipitated by the addition of cold $\mathrm{Et}_{2} \mathrm{O}$. The mixture was vortexed for $30 \mathrm{sec}$ and the precipitate was centrifuged down (4000 rpm for $5 \mathrm{~min}$ ). The supernatant was discarded the precipitation was suspended in $\mathrm{Et}_{2} \mathrm{O}$, sonicated and centrifuged down as described above two times. The crude peptide (3c) was lyophilized and used to convert it to MPAA thioester.

The thioester conversion was performed in multiple batches. For one batch $80 \mathrm{mg}$ crude (3c) peptide was dissolved in $4.0 \mathrm{ml} \mathrm{Gn \cdot HCl}$ buffer. Separately MPAA (108.0 mg, 0.64 $\mathrm{mmol})$, TCEP.HCl $(91.5 \mathrm{mg}, 0.32 \mathrm{mmol})$ and acac $(3.3 \mu \mathrm{L}, 0.03 \mathrm{mmol})$ were dissolved in $2.0 \mathrm{ml} \mathrm{Gn} \cdot \mathrm{HCl}$ buffer and the $\mathrm{pH}$ was set to 3.0. The MPAA containing buffer was added to the solution of the crude peptide, the $\mathrm{pH}$ was readjusted to 3.0 and the mixture was incubated at rt for 20 hours.

Purification of crude peptide 3 was performed by preparative HPLC using C4 $(50 \times 250 \mathrm{~mm})$ with a gradient of 25 to $65 \% \mathrm{CH}_{3} \mathrm{CN}$ with $0.1 \%$ TFA in $40 \mathrm{~min}$. The pure product fractions were pooled and lyophilized to obtain 3 (60 mg, $8.9 \mu \mathrm{mol}, 4.4 \%$ yield for peptide synthesis, resin cleavage, thioester conversion and purification steps). 
A)

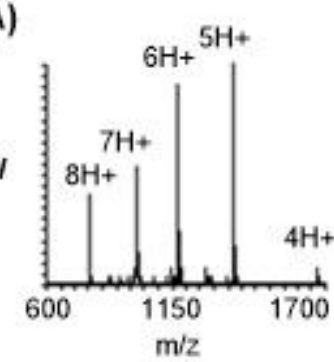

B)

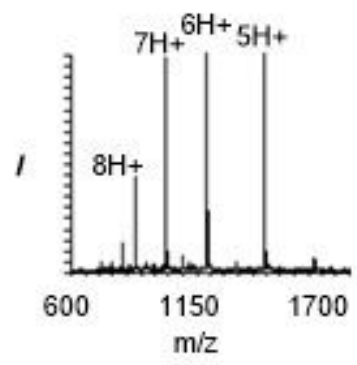

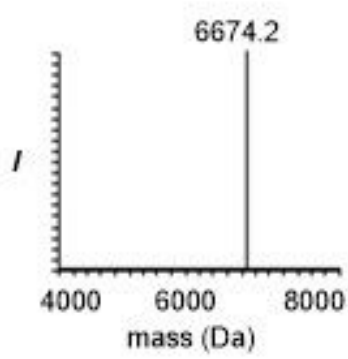

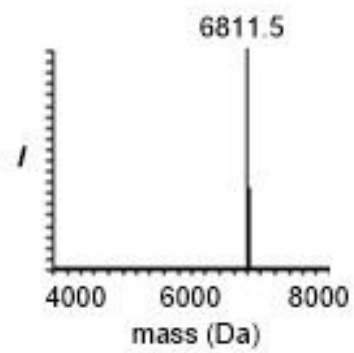

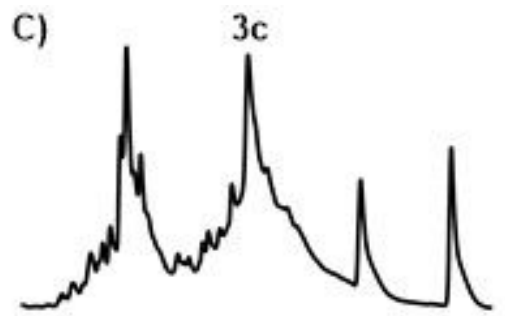
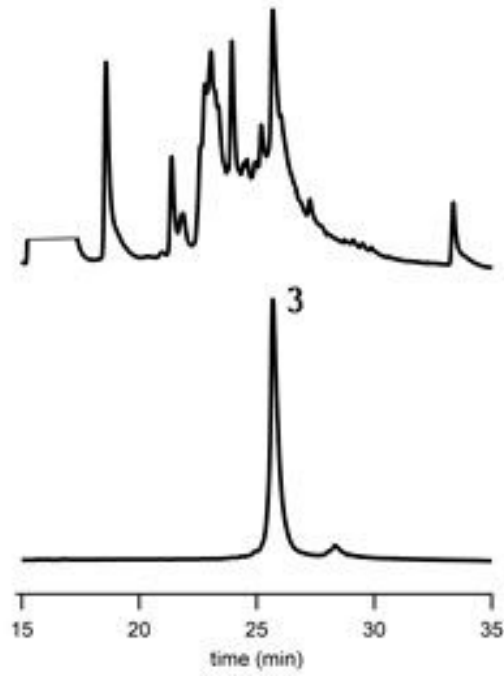

Figure S3: A) Measured and deconvoluted ESI-MS trace of intermediate 3c observed mass 6674.2 $\pm 0.4 \mathrm{Da}$; calcd 6675.8 Da. B) Measured and deconvoluted ESI-MS trace of purified compound 3 observed mass $6811.6 \pm 0.5 \mathrm{Da}$; calcd 6812.0 Da. C) HPLC trace of crude 3c, crude 3 after thioesterification and purified 3.

\subsection{Synthesis of ISG15 (61-157) cysteine segment (4)}

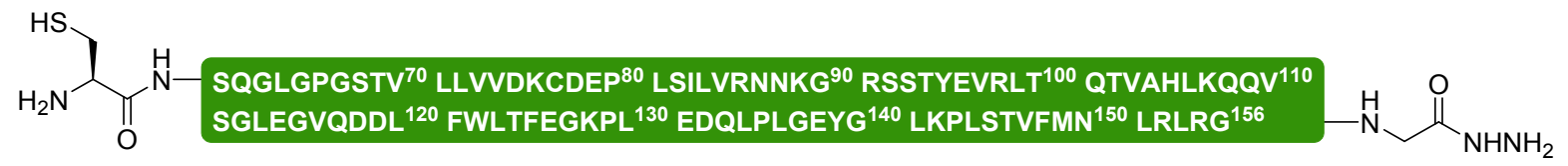

2-chlorotrityl chloride resin was let to swell in $10 \mathrm{ml} \mathrm{DMF:} \mathrm{CH}_{2} \mathrm{Cl}_{2}$ mixture (1:1) for 0.5 hours. The resin was washed 3 times with DMF and treated for 0.5 hours with $10 \mathrm{ml} 10 \%$ solution of hydrazine in DMF. The washing and the hydrazine treatment were repeated one time. The resin was capped by treatment of $5 \mathrm{v} / \mathrm{v} \% \mathrm{MeOH}$ in DMF for 0.5 hours two times. FmocGly-OH (297.0 mg, $0.2 \mathrm{mmol}, 1.0$ equiv) was coupled on the resin for 20 hours using HATU (1.0 equiv) and DIPEA (2.0 equiv). After the coupling of the Fmoc-Gly-OH, the resin was capped using $\mathrm{Ac}_{2} \mathrm{O}$ (10 equiv) and DIPEA (10 equiv) for 10 minutes. 
The peptide synthesis was performed on $0.2 \mathrm{mmol}$ scale in automated fashion using standard Fmoc-AA-OH (4.0 equiv) building blocks, HCTU (4.0 equiv) coupling reagent and DIPEA (8.0 equiv) for 45 minutes in DMF, double couplings were performed in each time.

From residue 83, the synthesis was continued in manual fashion using standard Fmoc-AA$\mathrm{OH}$ (4.0 equiv) building blocks, HATU (4.0 equiv) coupling reagent and DIPEA (8.0 equiv) for $0.5 \mathrm{~h}$ in NMP, double couplings were performed in each time and after coupling the resin was capped with $\mathrm{Ac}_{2} \mathrm{O}$ (10 equiv) and DIPEA (10 equiv) in DMF for 10 minutes unless otherwise specified. In order to avoid unwanted oxidation, the methionine residues were replaced by norleucine using Fmoc-Nle-OH building block.

The cysteine residue was coupled using Boc-Cys(Trt)-OH (4.0 equiv), $\mathrm{HOBt}$ (4.0 equiv) and DIC (4.0 equiv) after 10 minutes of preactivation in DMF for 2 hours. The capping was performed as described above.

Pseudoproline dipeptides were used in the cases of ST, LT, VS. Fmoc-AA$\mathrm{Ser} / \mathrm{Thr}(\Psi \mathrm{Me}, \mathrm{Me})-\mathrm{OH}$ (2.5 equiv) were coupled using HATU (2.5 equiv) coupling reagent and DIPEA (5.0 equiv) for $2 \mathrm{~h}$ in DMF. The capping was performed as described above.

The peptide was cleaved from resin with the following cleavage cocktail: $95 \mathrm{v} / \mathrm{v} \%$ TFA; 2.5 $\mathrm{v} / \mathrm{v} \% \mathrm{DODT} ; 2.5 \mathrm{v} / \mathrm{v} \% \mathrm{H}_{2} \mathrm{O}$ for 2 hours at rt. $10 \mathrm{~mL}$ cleavage cocktail was used for $1.0 \mathrm{~g}$ of peptidic resin. After 2 hours the resin was filtered off and peptide was precipitated by the addition of cold $\mathrm{Et}_{2} \mathrm{O}$. The mixture was vortexed for $30 \mathrm{sec}$ and the precipitate was centrifuged down (4000 rpm for $5 \mathrm{~min}$ ). The supernatant was discarded the precipitation was suspended in $\mathrm{Et}_{2} \mathrm{O}$, sonicated and centrifuged down as described above two times. The crude peptide (4) was lyophilized.

Purification of crude peptide 4 was performed by preparative HPLC using C4 $(50 \times 250 \mathrm{~mm}$ ) with a gradient of 25 to $65 \% \mathrm{CH}_{3} \mathrm{CN}$ with $0.1 \%$ TFA in $40 \mathrm{~min}$. The pure product fractions were pooled and lyophilized to obtain 4 (50 mg, $4.7 \mu \mathrm{mol}, 2.4 \%$ yield for peptide synthesis, resin cleavage and purification steps). 

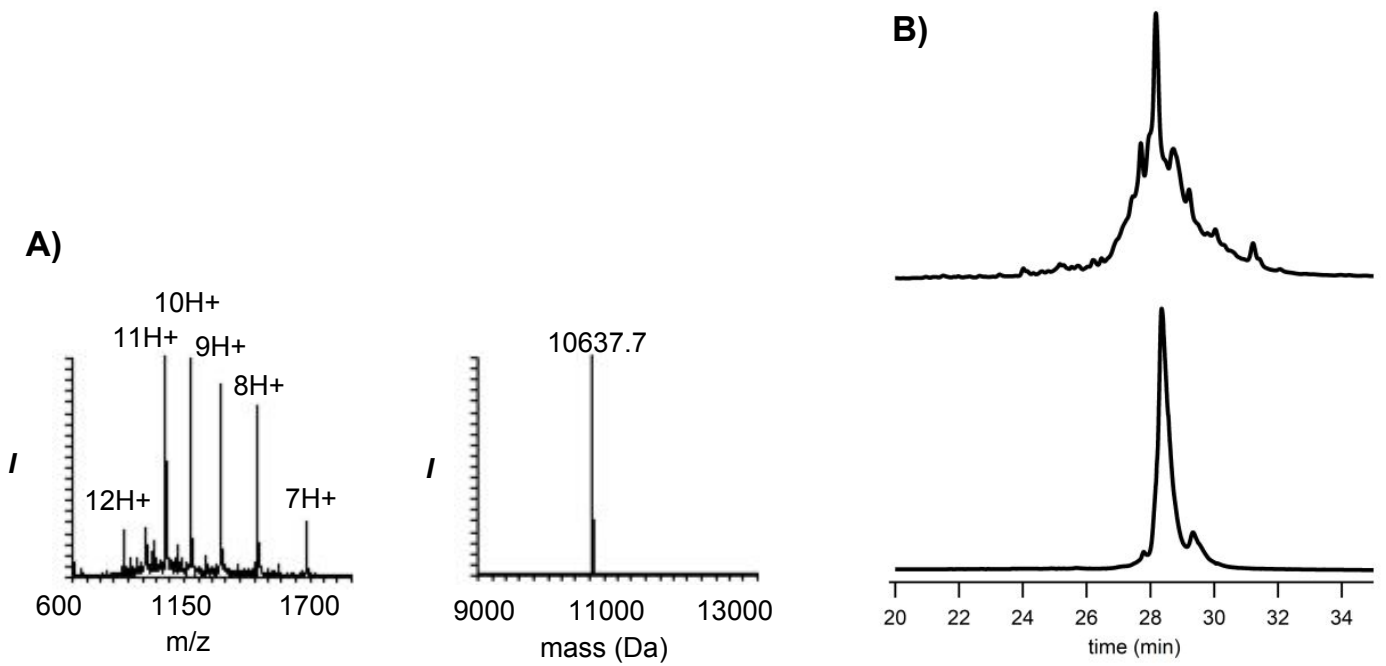

Figure S4: A) Measured and deconvoluted ESI-MS trace of compound 4. B) HPLC trace of crude and purified compound 4, observed mass $10637.7 \pm 0.6 \mathrm{Da}$; calcd 10639.2 Da.

\subsection{Synthesis of Ub (K29 thiolysine) segment (6)}

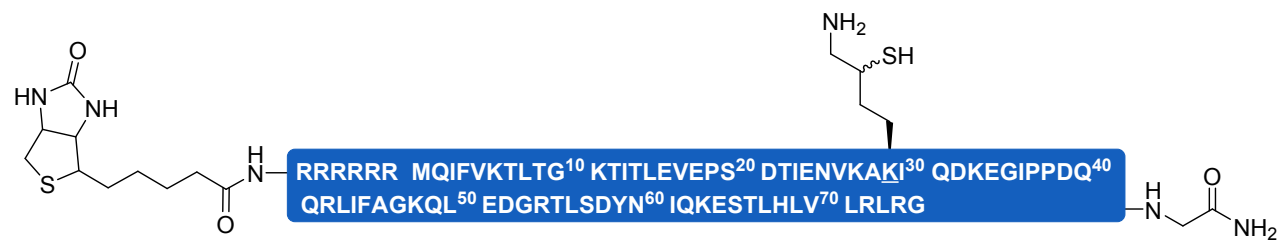

Peptide synthesis was performed on $0.2 \mathrm{mmol}$ scale $(770 \mathrm{mg}$ Rink amide resin with a substitution capacity of $0.26 \mathrm{mmol} / \mathrm{g}$ ) in automated fashion using standard Fmoc-AA-OH (4.0 equiv), HCTU (4.0 equiv) coupling reagent and DIPEA (8.0 equiv) for 45 minutes in DMF, double couplings were performed in each time and after coupling the resin was capped with $\mathrm{Ac}_{2} \mathrm{O}$ (10 equiv) and DIPEA (10 equiv) in DMF for 10 minutes unless otherwise specified. In order to avoid unwanted oxidation, the methionine residues were replaced by norleucine using Fmoc-Nle-OH building block.

Pseudoproline dipeptides were used in the cases of ST, LS, IT, LT. Fmoc-AA$\mathrm{Ser} / \mathrm{Thr}(\Psi \mathrm{Me}, \mathrm{Me})-\mathrm{OH}$ (2.5 equiv) were coupled using HATU (2.5 equiv) coupling reagent and DIPEA (5.0 equiv) for $2 \mathrm{~h}$ in DMF. The capping was performed as described above. In order to avoid aspartimide formation Fmoc-Asp(OtBu)-(Dmb)Gly-OH 2.5 equiv) were 
coupled using HATU (2.5 equiv) coupling reagent and DIPEA (5.0 equiv) for $2 \mathrm{~h}$ in DMF. The capping was performed as described above.

Fmoc- $\delta$-mercapto-Lys(Boc)-OH (2.5 equiv) were coupled using HATU (2.5 equiv) coupling reagent and DIPEA (5.0 equiv) for $2 \mathrm{~h}$ in DMF. The capping was performed as described above.

The peptide was cleaved from resin with the using the cleavage cocktail: $95 \mathrm{v} / \mathrm{v} \%$ TFA; 2.5 $\mathrm{v} / \mathrm{v} \%$ DODT; $2.5 \mathrm{v} / \mathrm{v} \% \mathrm{H}_{2} \mathrm{O}$ for 2 hours at rt. $10 \mathrm{~mL}$ cleavage cocktail was used for $1 \mathrm{~g}$ of peptidic resin. After 2 hours the resin was filtered off and peptide was precipitated by the addition of cold $\mathrm{Et}_{2} \mathrm{O}$. The mixture was vortexed for $30 \mathrm{sec}$ and the precipitate was centrifuged down (4000 rpm for $5 \mathrm{~min}$ ). The supernatant was discarded the precipitation was suspended in $\mathrm{Et}_{2} \mathrm{O}$, sonicated and centrifuged down as described above two times. The crude peptide (6a) was lyophilized.

The thiazolidine opening conversion was performed in multiple batches. For one batch 60 $\mathrm{mg}$ crude (6a) peptide was dissolved in $2 \mathrm{ml} \mathrm{Gn} \cdot \mathrm{HCl}$ buffer. Separately $\mathrm{MeNHOH} \bullet \mathrm{HCl}(40.8$ $\mathrm{mg}, 0.49 \mathrm{mmol}), \mathrm{TCEP} \cdot \mathrm{HCl}(88.0 \mathrm{mg}, 0.31 \mathrm{mmol})$ were dissolved in $1 \mathrm{ml} \mathrm{Gn} \cdot \mathrm{HCl}$ buffer. After complete dissolution of the reagents the two buffers were combined and incubated at $37^{\circ} \mathrm{C}$ for 20 hours.

Purification of crude peptide 6 was performed by preparative HPLC using C18 Phenomenex preparative column $(50 \times 250 \mathrm{~mm})$ with a gradient of 15 to $45 \% \mathrm{CH}_{3} \mathrm{CN}$ with $0.1 \%$ TFA in $40 \mathrm{~min}$. The pure product fractions were pooled and lyophilized to obtain $6(32 \mathrm{mg}, 3.3 \mu \mathrm{mol}$, $2.0 \%$ yield for peptide synthesis, resin cleavage, thiazolidine opening and purification steps). 


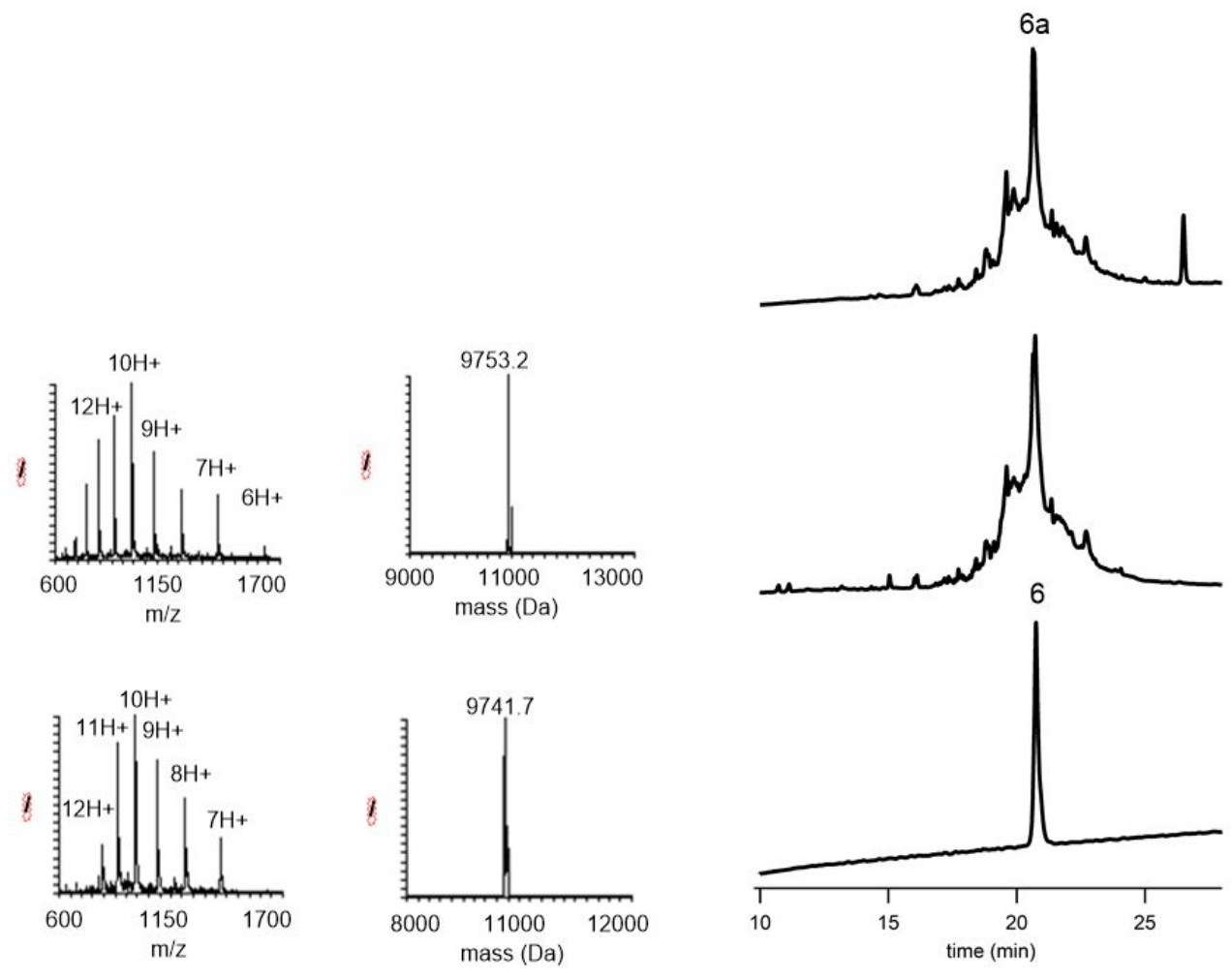

Figure S5: A) Measured and deconvoluted ESI-MS trace of Thz closed 6a, observed mass 9753.2 \pm 0.3 Da; calcd 9753.4 Da. B) Measured and deconvoluted ESI-MS trace of purified compound 6, observed mass $9741.7 \pm 0.9 \mathrm{Da}$; calcd 9741.3 Da. C) HPLC trace of crude peptide after SPPS, crude 6a after thiazolidine opening and purified 6 . 


\subsection{Assembly of the full length ISG15 by NCL and subsequent thioester conversion}

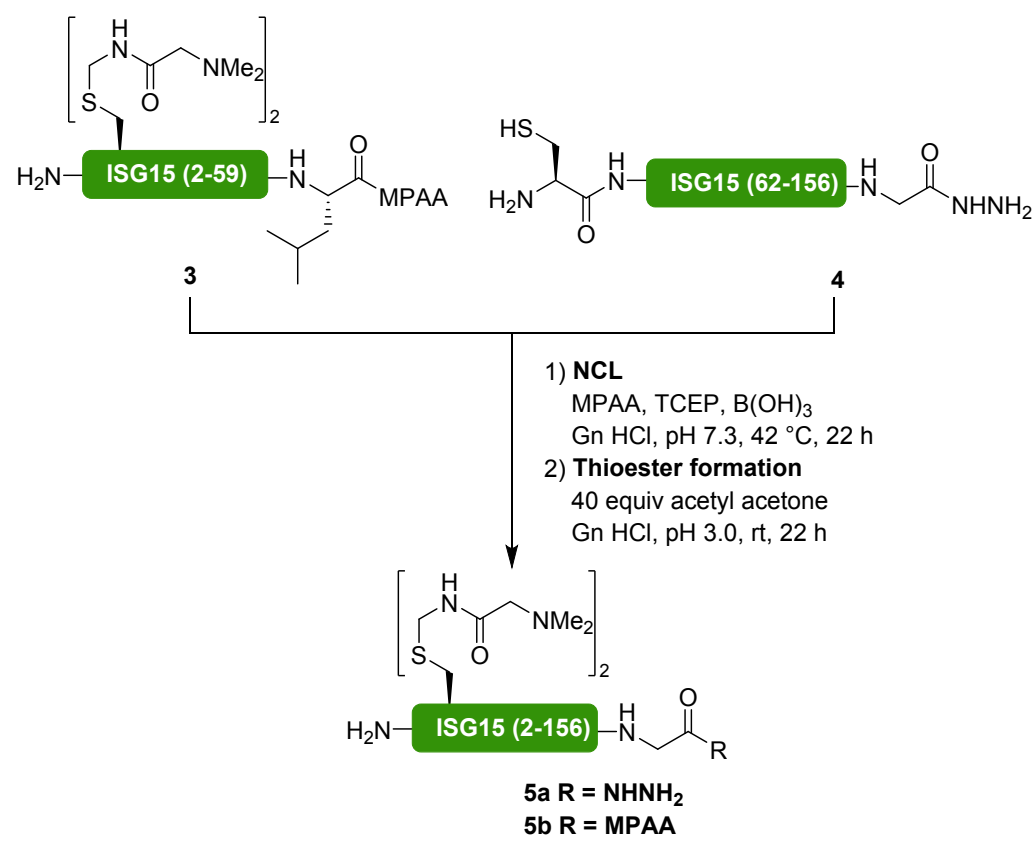

Thioester fragment $3(2.0 \mathrm{mg}, 0.3 \mu \mathrm{mol}, 1.0$ equiv) and cysteine fragment $4(2.2 \mathrm{mg}, 0.2$ $\mu \mathrm{mol}, 0.7$ equiv) were dissolved in $173 \mu \mathrm{L} \mathrm{Gn} \bullet \mathrm{HCl}$ buffer containing MPAA (68 mM, 40 equiv), TCEP. $\mathrm{HCl}(34 \mathrm{mM}, 20$ equiv), boric acid $(25 \mathrm{mM})$ to result $1.7 \mathrm{mM}$ final concentration of thioester fragment. The mixture was incubated at $42{ }^{\circ} \mathrm{C}$ for 22 hours. After the HPLC showed full conversion, further $173 \mu \mathrm{L}$ of the same buffer, containing acac (34 mM), was added and the $\mathrm{pH}$ was adjusted to 3.0 and the mixture was incubated at it for 22 hours.

The ligated product $\mathbf{5 b}$ was purified using semi-preparative HPLC using C4 Phenomenex preparative column $(50 \times 250 \mathrm{~mm})$ with a gradient of 25 to $65 \% \mathrm{CH}_{3} \mathrm{CN}$ with $0.1 \%$ TFA in $35 \mathrm{~min}$. The pure product fractions were pooled and lyophilized to obtain $\mathbf{5 b}(1 \mathrm{mg}, 0.06$ $\mu \mathrm{mol}, \mathbf{2 8 . 0} \%$ yield for peptide ligation, and thioester conversion steps). 

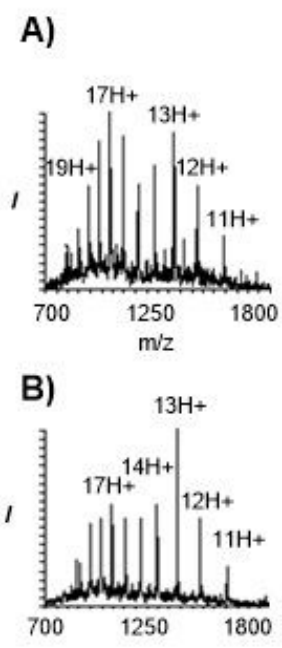
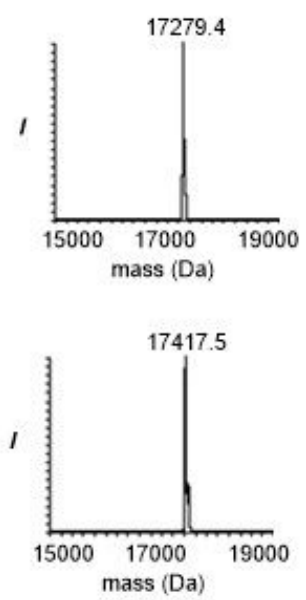
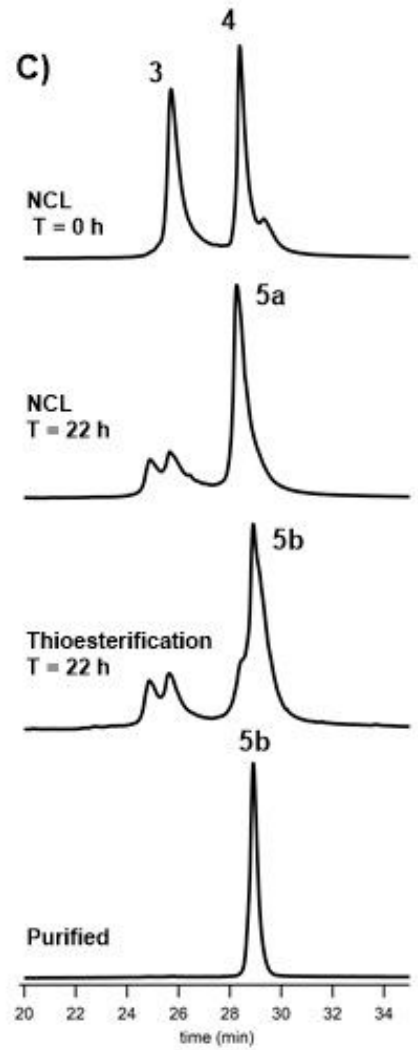

Figure S6: A) Measured and deconvoluted ESI-MS trace of 5a, observed mass $17279.4 \pm 2.0 \mathrm{Da}$; calcd 17283.0 Da. B) Measured and deconvoluted ESI-MS trace of purified compound $\mathbf{5 b}$, observed mass $17417.5 \pm 1.8 \mathrm{Da}$; calcd 17419.1 Da. C) HPLC trace of NCL and thioester forming reaction.

\subsection{NCL ligation between full length ISG15 and ubiquitin fragment}

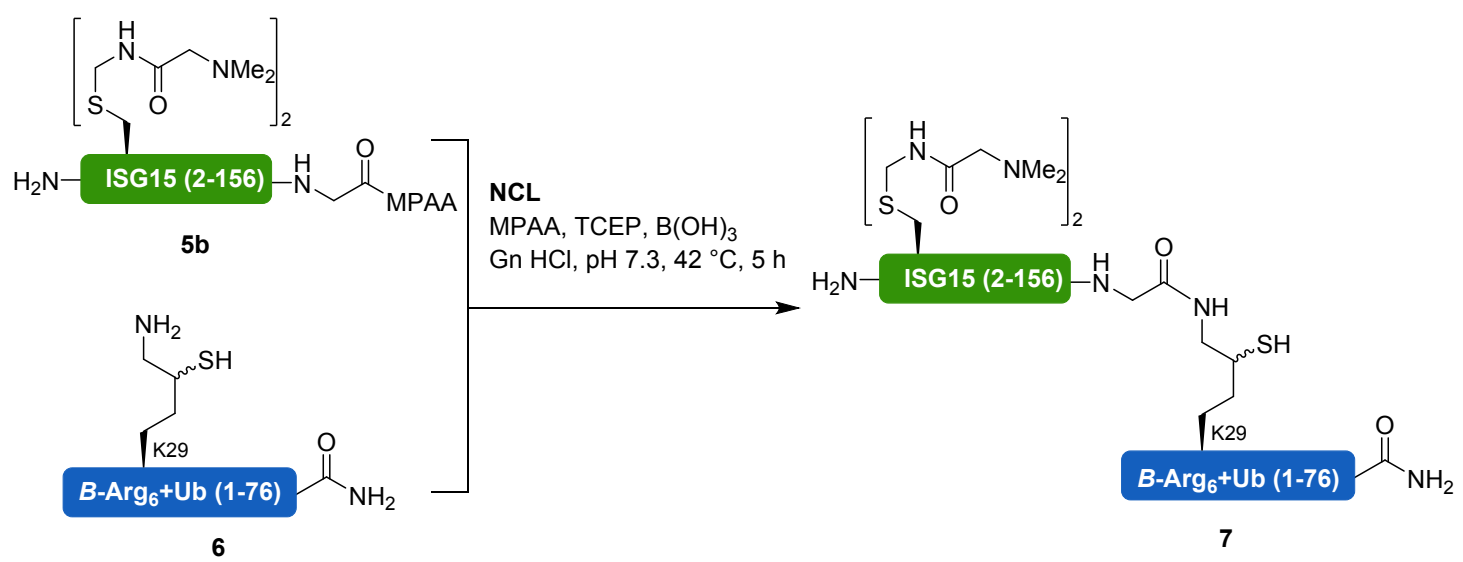


Thioester fragment $\mathbf{5 b}$ (1.2 mg, $0.7 \mu \mathrm{mol}, 1.0$ equiv) and fragment $6(0.9 \mathrm{mg}, 0.9 \mu \mathrm{mol}, 1.3$ equiv) were dissolved in $69 \mu \mathrm{L} \mathrm{Gn \bullet HCl}$ buffer containing MPAA (50 mM, 50 equiv), TCEP. $\mathrm{HCl}(25 \mathrm{mM}, 25$ equiv), boric acid $(25 \mathrm{mM})$ to result $1.0 \mathrm{mM}$ final concentration of thioester fragment. The proteins showed very poor solubility and required intense vortexing in order to fully dissolve them. The mixture was incubated at $42{ }^{\circ} \mathrm{C}$ for 5 hours.

The ligated product 7 was purified using semi-preparative HPLC using C4 Phenomenex preparative column $(50 \times 250 \mathrm{~mm})$ with a gradient of 25 to $65 \% \mathrm{CH}_{3} \mathrm{CN}$ with $0.1 \%$ TFA in $35 \mathrm{~min}$. The pure product fractions were pooled and lyophilized to obtain $7(0.5 \mathrm{mg}, 0.02$ $\mu \mathrm{mol}, 27 \%$ yield for ligation).
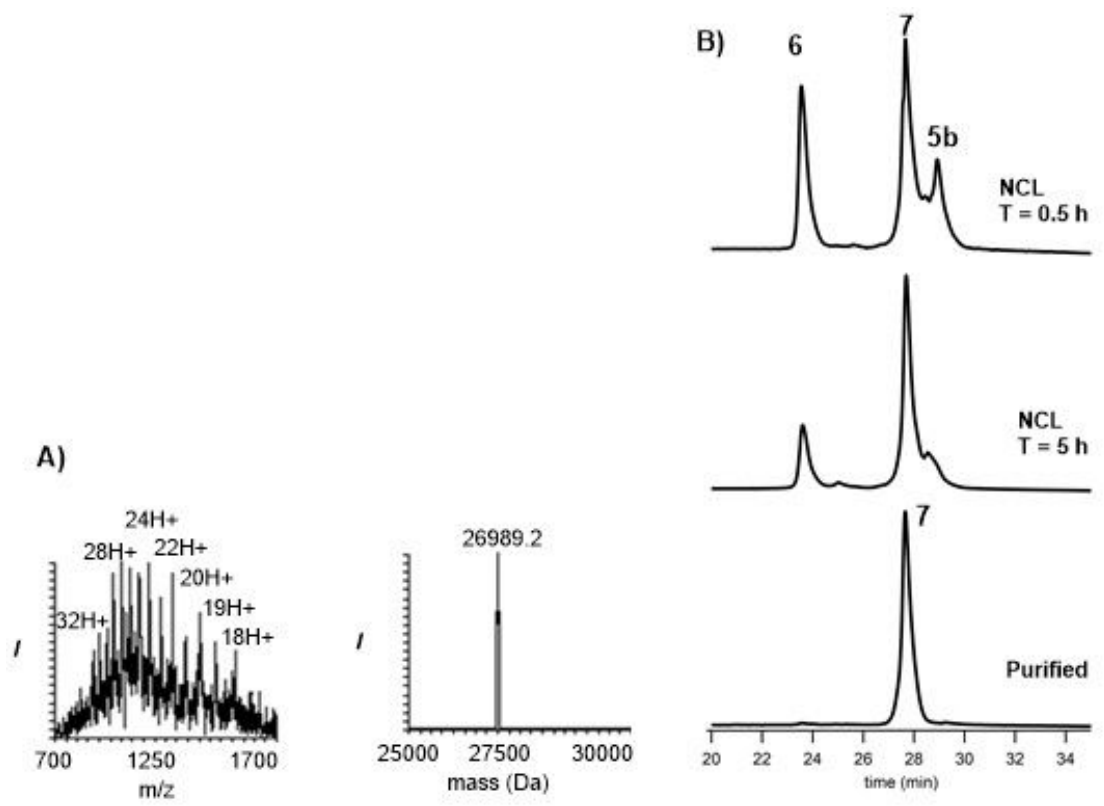

Figure S7: A) Measured and deconvoluted ESI-MS trace of 7, observed mass $26989.2 \pm 4.6 \mathrm{Da}$; calcd 26992.2 Da. B) HPLC trace of NCL 


\subsection{Cysteine deprotection and desulfurization}

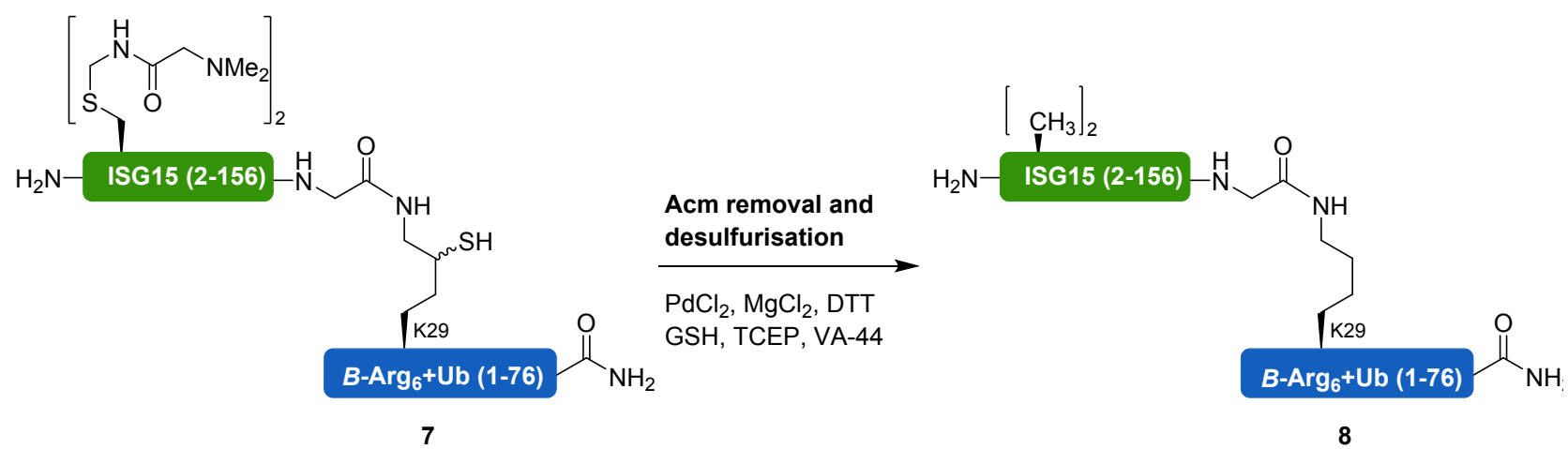

Cysteine protected ISG15-Ub protein $7(0.5 \mathrm{mg}, 20 \mathrm{nmol}, 1.0$ equiv) was dissolved in $20 \mu \mathrm{L}$ $\mathrm{Gn} \cdot \mathrm{HCl}$ buffer and incubated at $37^{\circ} \mathrm{C}$ for 10 minutes. $5 \mu \mathrm{L} \mathrm{Gn} \cdot \mathrm{HCl}$ buffer containing $\mathrm{MgCl}_{2}$ (100 equiv) was added and incubated for further 10 minutes at $37^{\circ} \mathrm{C} .5 \mu \mathrm{L} \mathrm{Gn} \cdot \mathrm{HCl}$ buffer containing $\mathrm{PdCl}_{2}$ (30 equiv) was added and incubated for 4 hours at $37^{\circ} \mathrm{C}$. The reaction was quenched by the addition of approximately $1 \mathrm{mg}$ DTT. The formed precipitate was centrifuged, the supernatant was taken and kept. The formed pellet was washed two times with $90 \mu \mathrm{L} \mathrm{Gn} \cdot \mathrm{HCl}$ buffer. The supernatant was combined with the washing solutions to result approximately $200 \mu \mathrm{L}$ solution containing the cysteine deprotected protein.

This mixture was dialyzed overnight against $15 \mathrm{~mL} \mathrm{Gn} \cdot \mathrm{HCl}$ buffer containing reduced glutathione $(20 \mathrm{mM})$. After dialysis the solution with the protein was taken and transferred into an eppendorf tube. TCEP.HCl (5.7 mg, 1000 equiv), VA-044 (1.3 mg, 200 equiv) were added and the mixture was incubated overnight at $37^{\circ} \mathrm{C}$.

The final product 8 was purified using analytical HPLC using C4 Phenomenex analytical column $(50 \times 250 \mathrm{~mm})$ with a gradient of 25 to $65 \% \mathrm{CH}_{3} \mathrm{CN}$ with $0.1 \%$ TFA in $65 \mathrm{~min}$ at 60 ${ }^{\circ} \mathrm{C}$. The pure product fractions were pooled and lyophilized to obtain $8(0.2 \mathrm{mg}, 7.5 \mathrm{nmol}$, $49 \%$ yield for cysteine deprotection and desulfurization). Our attempts failed to measure MS for the final product, thus the identity of the protein was confirmed by tryptic digestion and LC-MS/MS. This procedure gave $81.51 \%$ coverage of the full protein. 
A)

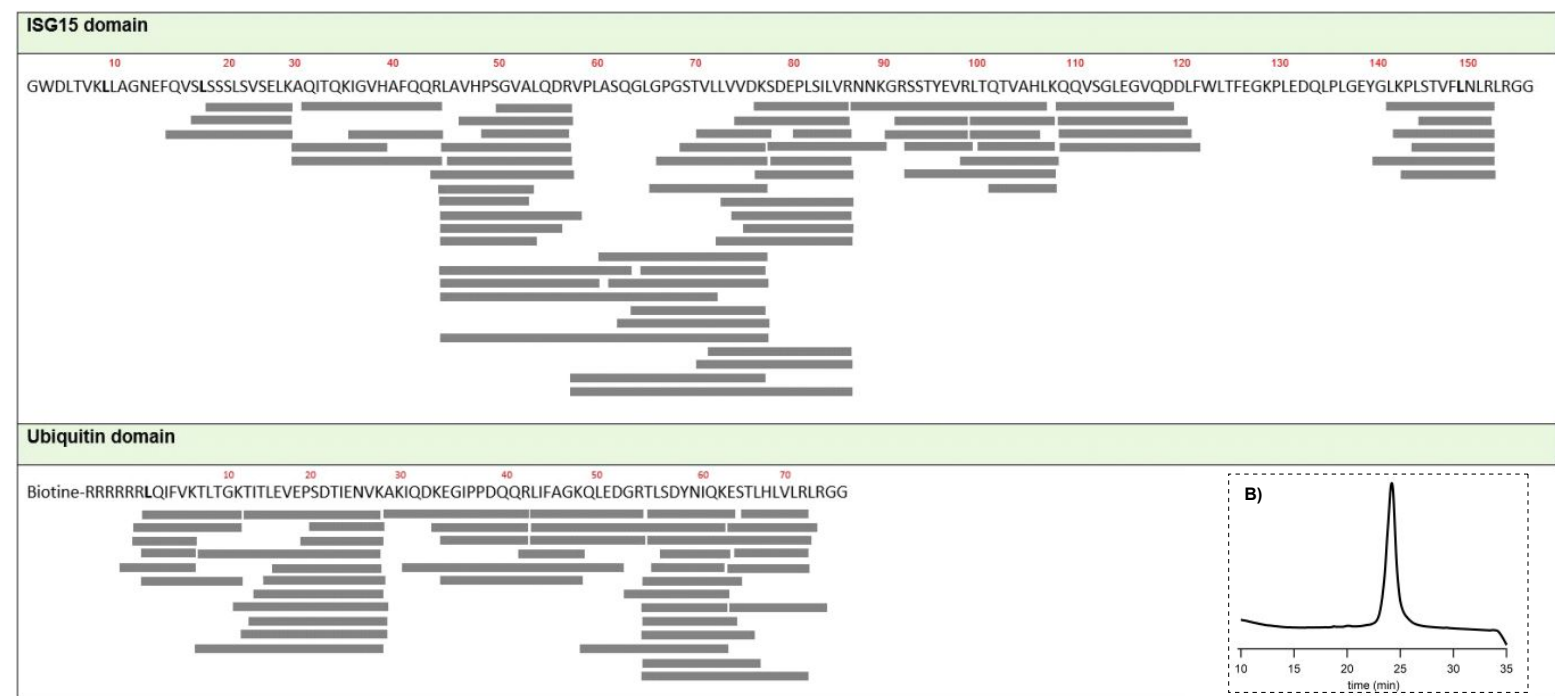

A) Sequence analysis of the product after tryptic digestion and LC-MS/MS digestion. The nolreucine residues are represented by $L$ in the sequence B) HPLC trace of the purified protein. 


\subsection{Western Blotting}
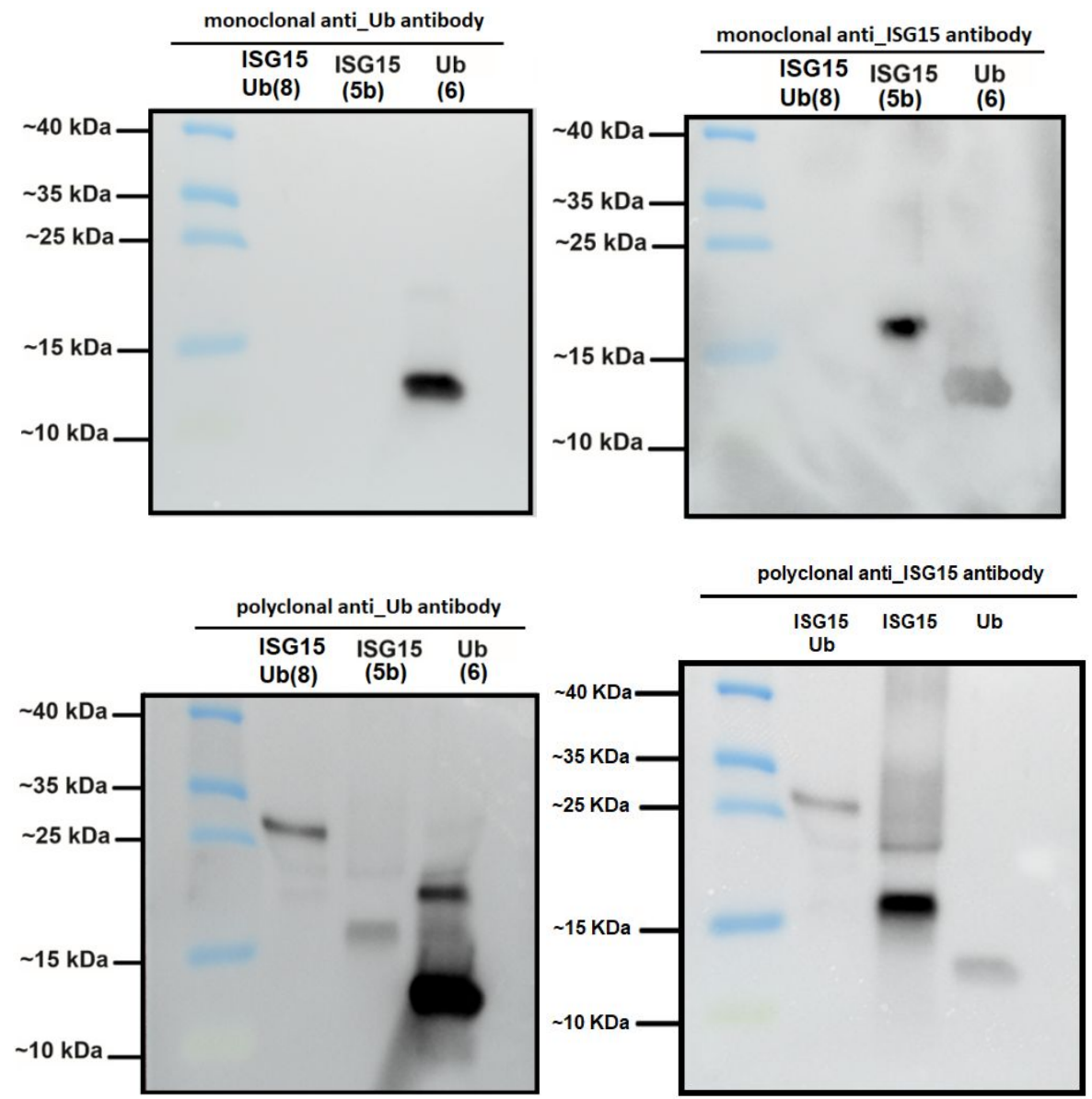

Figure S8: western blot using mono/polyclonal ISG15/Ub antibody (the antibodies are listed in the Reagents and Solvents section).

\subsection{Folding of the ISG15-Ub protein}

During the attempt for folding the protein many different folding buffers were used including: 50 mM Tris, 150-300 mM NaCl, pH 7-7.8; 20 mM HEPES, 150 mM NaCl, pH 6.5-7.5 ; PBS buffer, pH 6.5-7.5; 50 mM Tris buffer, $150 \mathrm{mM} \mathrm{NaCl}, \mathrm{pH} 8.4$, with $5 \% \mathrm{v} / \mathrm{v}[6 \mathrm{M} \mathrm{Gn \bullet HCl}$ buffer at $\mathrm{pH}$ 6] ; $10 \mathrm{mM}$ Tris buffer, $150 \mathrm{mM} \mathrm{NaCl}, 20 \%$ v/v glycerol, $\mathrm{pH} 8$; $45 \mathrm{mM} \mathrm{Na}_{2} \mathrm{HPO}_{4}$, $150 \mathrm{mM} \mathrm{NaCl}, 5 \mathrm{mM}$ Mercaptoethanol, 20\% (v/v) Glycerol. However, none of the buffers enabled us to obtain CD measurement of the protein in its folded structure. Fortunately, we were able to fold the protein by dissolving it $(0.1 \mathrm{mg}, 3.8 \mathrm{nmol})$ in $2 \mu \mathrm{L} \mathrm{Gn} \bullet \mathrm{HCl}$ buffer and rapidly adding a mixture of $144 \mu \mathrm{L}$ folding buffer containing boric acid ( $25 \mathrm{mM}$ ) glycerol 40 v/v\% at $\mathrm{pH} 6.2$ and $14 \mu \mathrm{L} 6 \mathrm{M} \mathrm{Gn} \cdot \mathrm{HCl}$ buffer at $0{ }^{\circ} \mathrm{C}$. 
The protein was incubated at $0{ }^{\circ} \mathrm{C}$ for 30 minutes, the formed precipitate was separated by centrifugation at $12.000 \mathrm{rpm}$ for 4 minutes. The final protein concentration was determined to be $5 \mu \mathrm{M}$ by Nanodrop.

\subsection{CD measurement}

The Circular Dichroism (CD) spectra was recorded in the folding buffer from $190 \mathrm{~nm}$ to 260 $\mathrm{nm}$.

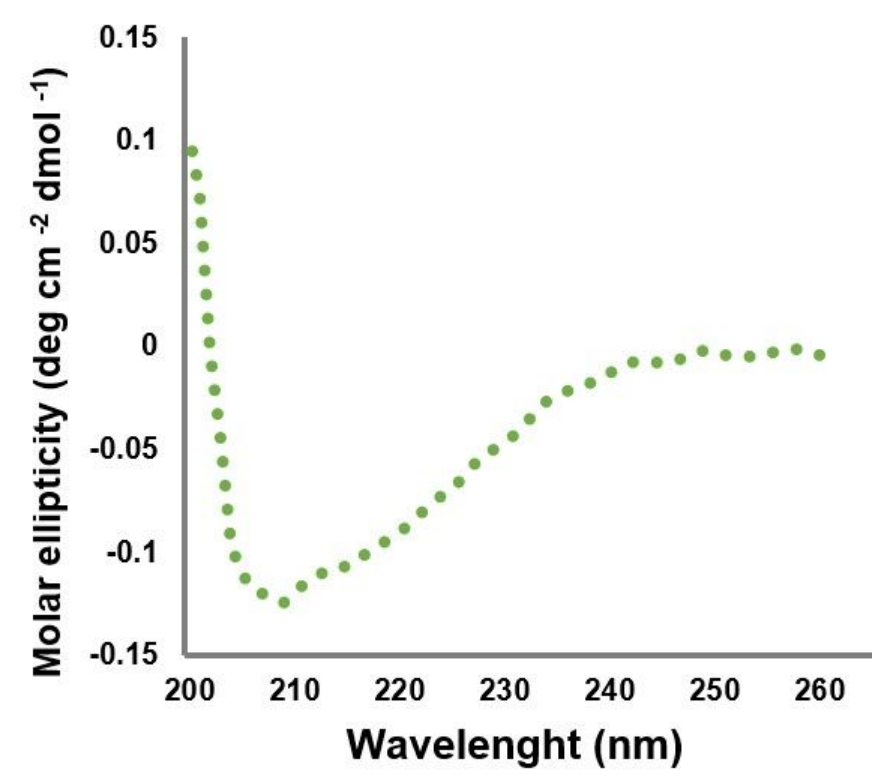

Figure S9: CD measurement of the folded ISG15-K29-Ub hybrid chain.

CD measurements were performed using a circular dichroism spectrometer Model Jasco 810 Spectropolarimeter and AppliedPhotophysics Chirascan. The ellipticity was measured as a function of wavelength from $200-300 \mathrm{~nm}$ at room temperatures using $0.05 \mathrm{~cm}$ cuvette $(\sim 100 \mu \mathrm{L}$ volume) with a scan time of $1 \mathrm{sec}$ per wavelength. The average of 3 consecutive repeated measurements is shown in Fig. S9 where the ellipticity (mdeg) was converted to molar ellipticity. 


\section{NMR spectra}

5.1. 2-(dimethylamino)acetamide (1b)

${ }^{1} \mathrm{HNMR}$

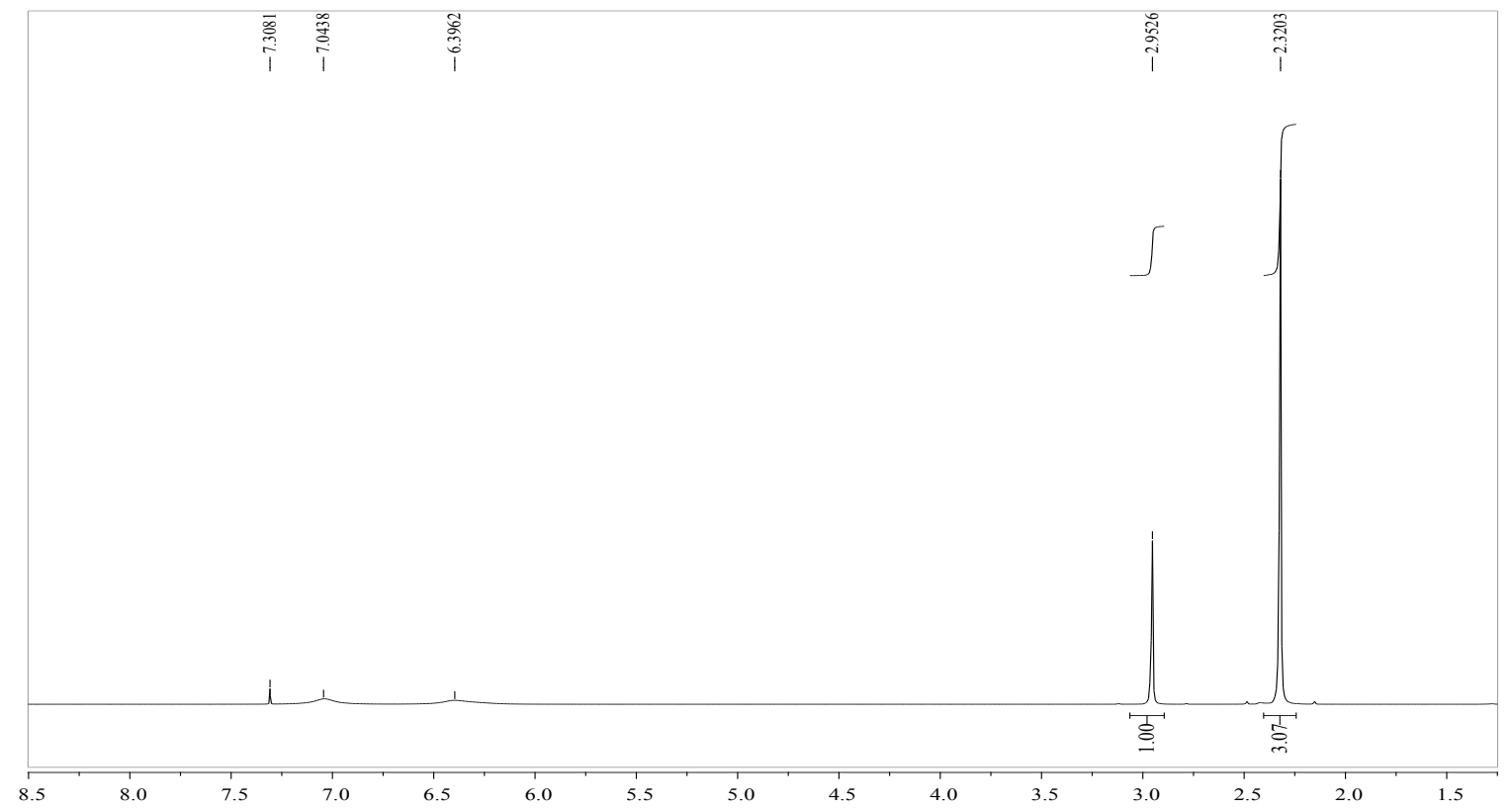

${ }^{13} \mathrm{C}$ NMR

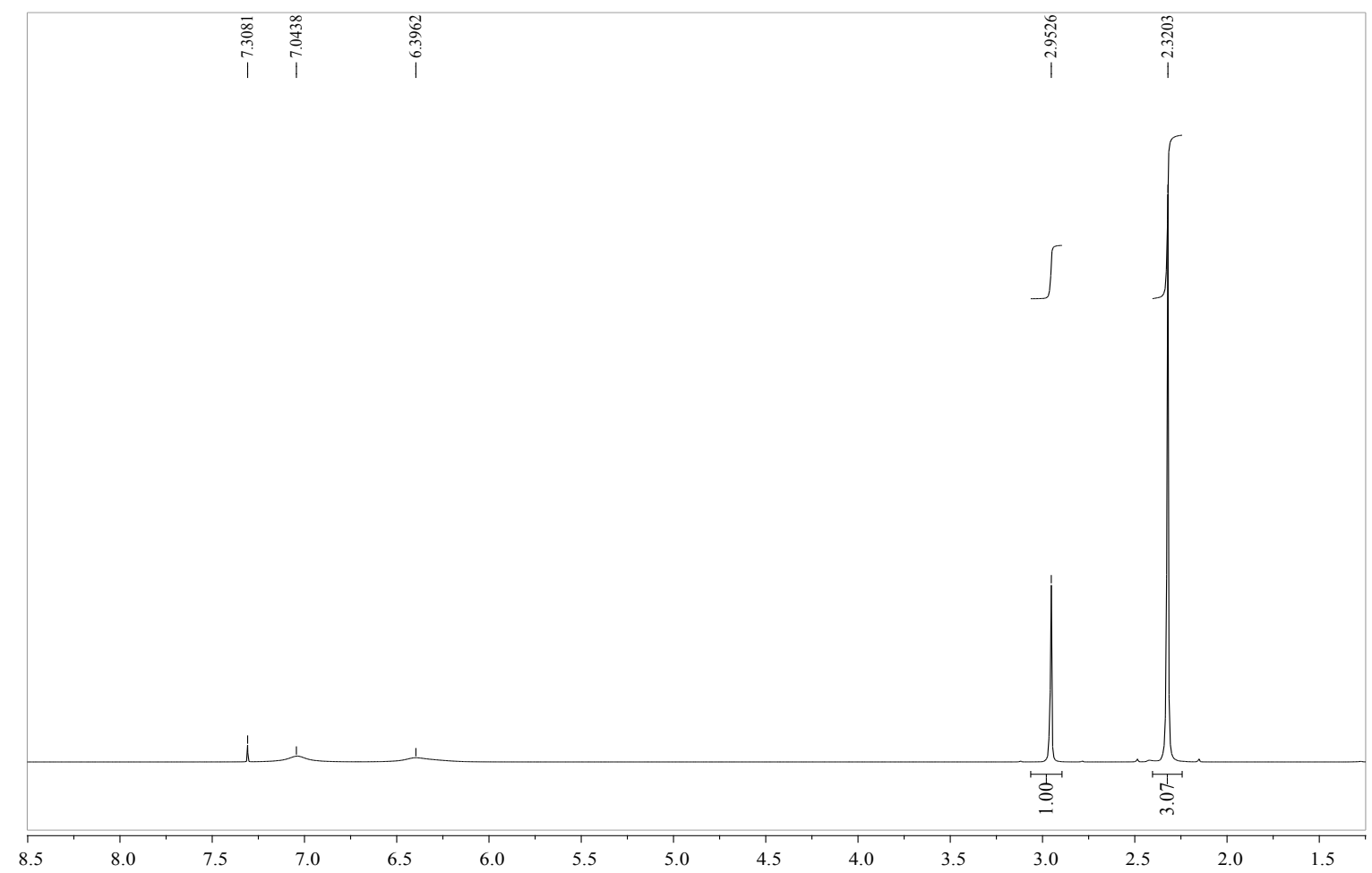

Page S24 of S25 
5.2. Fmoc-Cys(S-(di-Met-Acm))-OH (2)

${ }^{1} \mathrm{HNMR}$

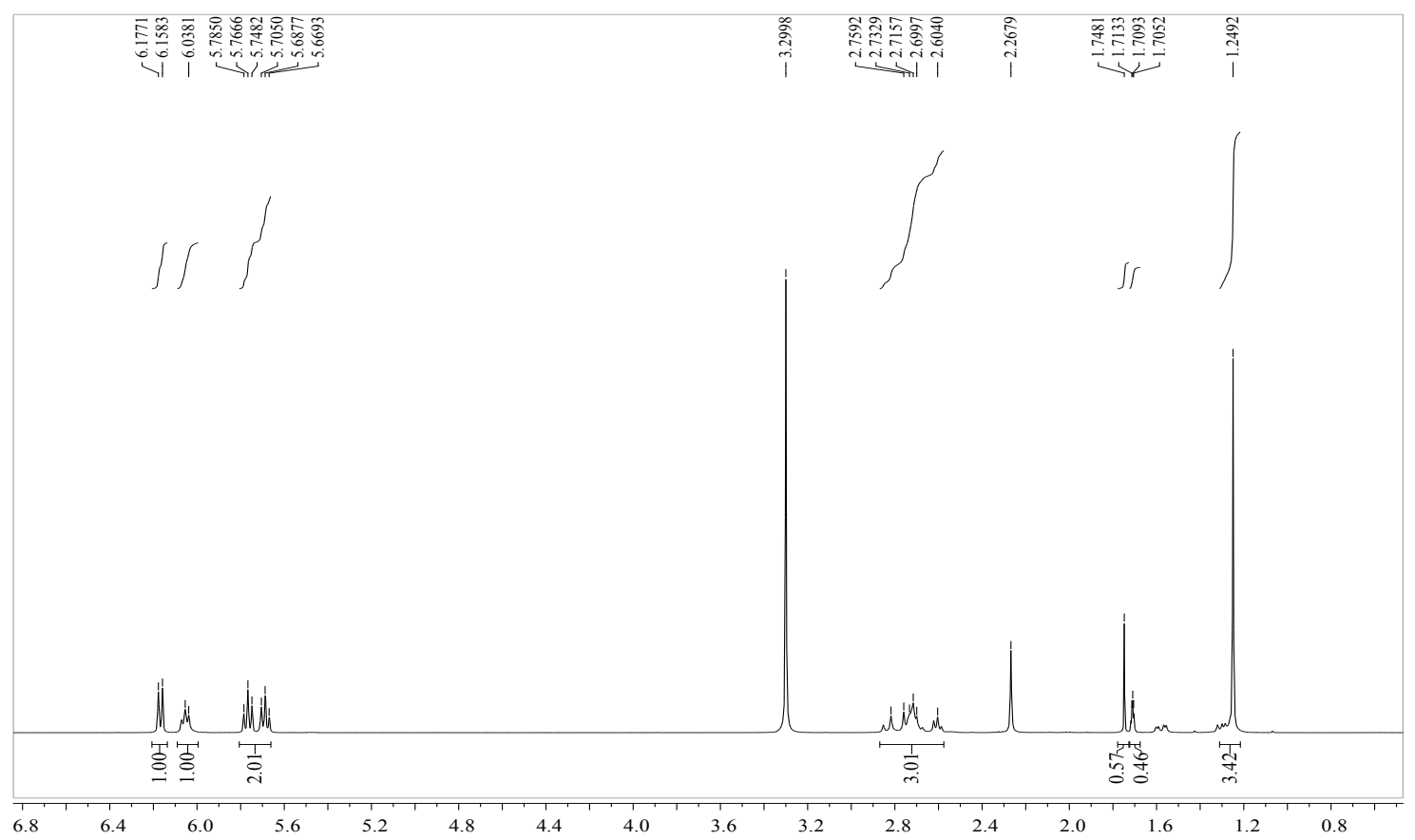

${ }^{13} \mathrm{C}$ NMR

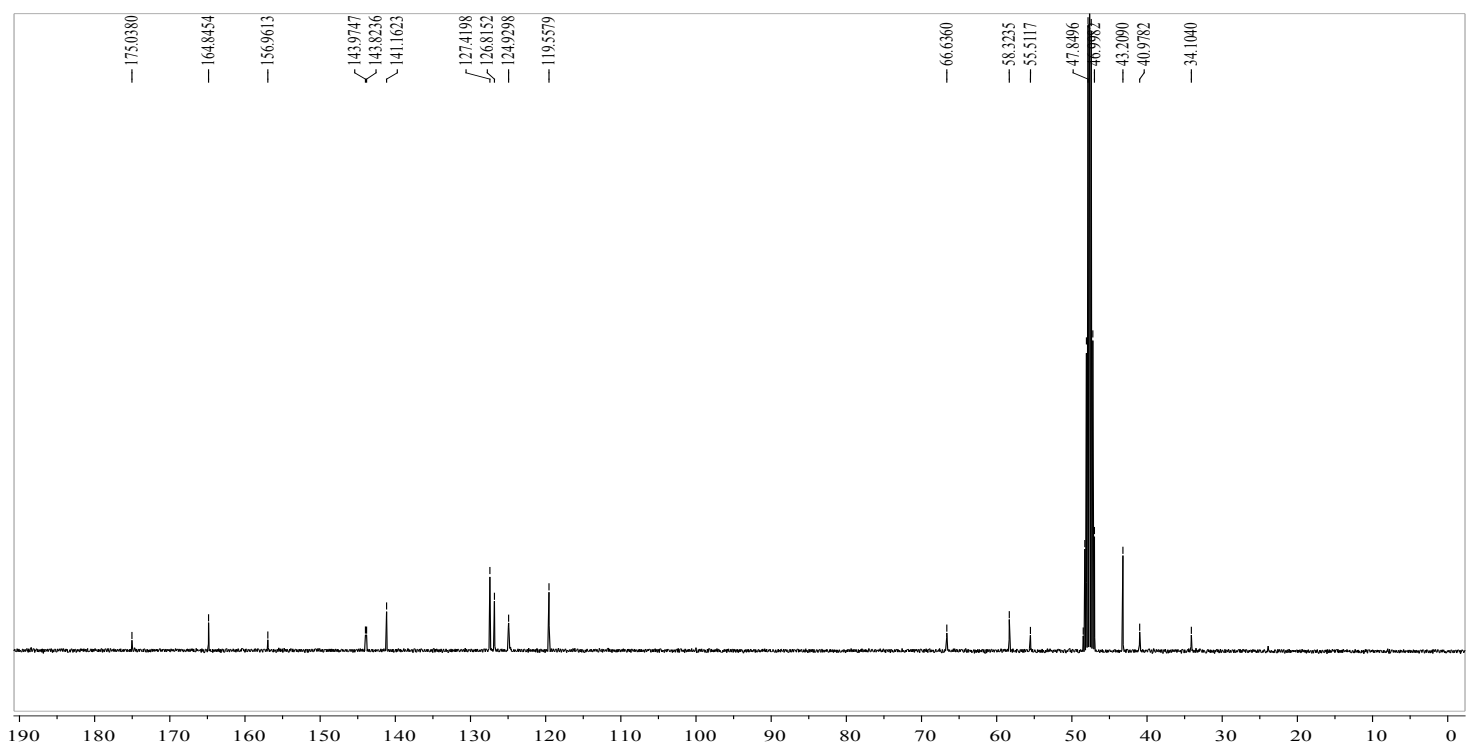

